\title{
MOTHER'S KNOWLEDGE ABOUT DIETARY HABIT DURING PREGNANCY IN PUSKESMAS SAMBAU, BATAM CITY
}

\author{
Miralza Diza ${ }^{1}$, Dyah Marianingrum ${ }^{2}$ \\ miralzadiza@univbatam.ac.id', dyahmarianingrum@univbatam.ac.id \\ Professional Doctor Study Program, Faculty of Medicine, Batam University ${ }^{1}$ \\ Medical Education Study Program, Faculty of Medicine, University of Batam ${ }^{2}$ \\ Jl. Abulyatama No 5
}

\begin{abstract}
Background : Fulfillment of nutritional intake and proper diet plays an important role in the health of both mother and fetus. Pregnant women with good nutritional knowledge can choose food intake that has good nutritional value and is balanced. Maternal nutritional status in pregnancy affects the nutritional status of the fetus. This study aims to determine the knowledge of mothers about diet during pregnancy.
\end{abstract}

Method : The research method used is descriptive. Conducted at the Sambau health center, the study was conducted for 6 months, the population in this study were pregnant women in the third trimester who had their pregnancies examined at the Sambau Health Center, totaling 140 pregnant women. The sample in this study is 30 people. The sampling technique was carried out by consecutive sampling with the research instrument using a questionnaire.

Result : The results showed that 18 respondents $(60 \%)$ had sufficient knowledge, as many as 8 respondents $(26.7 \%)$ had good knowledge and 4 respondents $(13.3 \%)$ had insufficient knowledge.

Conclusion : more than half of the respondents have sufficient knowledge (60\%). Suggestions for respondents to increase knowledge and increase motivation or guidelines for mothers about choosing a pregnant woman's diet

Keywords: Knowledge, pregnant women, diet

\section{PRELIMINARY}

The nutritional needs of pregnant women increase with increasing gestational age. The fulfillment of increased nutritional intake of pregnant women plays an important role in the health of the mother and the fetus. Fetal growth and development requires adequate energy and protein intake (Arkkola, 2009).

The nutritional status of pregnant women will have an impact on birth weight, perinatal mortality rate, perinatal health condition, and infant growth after birth. One of the factors that affect the nutrition of pregnant women is the knowledge of pregnant women and their families about nutrients in food. The preparation of the diet of pregnant women is influenced by: the ability of the family to buy food and knowledge of nutrition

Pregnant women weight gain can be used as an index to determine the nutritional status of pregnant women, because there is a similarity in the amount of weight gain during pregnancy for all pregnant women. The average total body weight gain for pregnant women ranges from $10-15 \mathrm{~kg}$, namely $1 \mathrm{~kg}$ in the first trimester and the rest in the second and third trimesters. From the II to III trimesters, the average weight gain was $0.3-0.7 \mathrm{~kg} /$ week. Therefore, mothers with malnutrition conditions during the last week of pregnancy will tend to give birth to babies with low body weight $(<2500 \mathrm{~g})$, because a lot of fat tissue is stockpiled during trimester III (Aritonang, 2011).

Low nutritional intake in pregnant women can result in babies born with low birth weight. A healthy reproductive process requires meeting the needs of energy, protein, carbohydrates, vitamins, minerals and fiber. Malnutrition problems will arise if in the long term the daily nutrient intake is lower than the recommended nutritional adequacy rate (Kemenkes RI, 2014; Pritasari et al, 2017). In a 
study pregnant women in Manado City had a diet that was low in carbohydrates, sufficient protein and high in fat (Narasiang et al., 2016). Diet is shaped by a person's habits in choosing food. Eating habits can be influenced by natural, environmental and cultural factors. A good dietary consumption pattern contains staple foods, side dishes, and vegetables and is eaten in sufficient quantities as needed. The habit of eating carbohydrate, protein and vegetable sources in pregnant women is related to the birth weight of babies in coastal areas (Saimindkk, 2019)

Maternal nutritional status before pregnancy has a significant effect on the incidence of LBW. Mothers with poor nutritional status before pregnancy have a 4.27 times risk of giving birth to LBW babies compared to mothers who have a good nutritional status (normal) (Nanni, 2007). the good one. Mothers who experience Chronic Energy Deficiency (KEK) during pregnancy will cause problems for both mother and fetus. Problems that occur in the mother can cause risks and complications. The nutritional status of a mother during pregnancy has a very important effect on both the health and the ability to produce breast milk and breastfeed the baby, nutritional needs will increase during pregnancy for the needs of the mother and fetus (Denok, 2004).

Nutritional problems experienced by pregnant women at this time are malnutrition such as Chronic Energy Deficiency (KEK) and nutritional anemia (Depkes RI, 1996). The prevalence of anemia in pregnant women in Indonesia is $70 \%$, or 7 out of 10 pregnant women suffer from anemia. Chronic Energy Deficiency (KEK) is found in female women aged 15-49 years which is indicated by the proportion of Upper Arm Circumference (LILA) $<23.5 \mathrm{~cm}$. Nutritional knowledge is knowledge about the relationship between food consumption and body health. Pregnant women with good nutritional knowledge are expected to be able to choose food intake with good nutritional value and balance for themselves and their fetus and family, with sufficient nutritional knowledge to help someone learn how to store, process and use quality food ingredients to be consumed according to their needs (Hastuti , 1996).

Research conducted by Anita, 2012 states that there is a significant influence between diet and the incidence of LBW with a value $(\mathrm{p}=0.000)$ in Pancur Batu sub-district, Deli Serdang district. Based on the logistic regression test, it is known that the variable with the most dominant influence on LBW OR $=28.076$ means that a bad diet has a 28.076 chance of giving birth to LBW compared to mothers with a good diet.

Based on the initial survey conducted at the Sambau Health Center, out of 10 pregnant women who came for ante natal care, only 4 people knew about a good diet for pregnant women and had done it daily, therefore the authors were interested in carrying out research with the title of knowledge diet at the Puskesmas Sambau, Batam City.

\section{RESEARCH PURPOSES}

This research was conducted to determine the knowledge of mothers about diet during pregnancy.

\section{RESEARCH METHODS}

The research method used is descriptive. Conducted at the Sambau health center, the study was conducted for 6 months, the population in this study were pregnant women in the third trimester who had their pregnancies examined at the Sambau Health Center, amounting to 140 pregnant women. The sample in this study is 30 people. The sampling technique was carried out by consecutive sampling with the research instrument using a questionnaire.

\section{RESEARCH RESULT \\ Table 1 Frequency Distribution of Respondents Based on Pregnant Mother's Knowledge of Diet at Puskesmas Batu Aji Batam City}

\begin{tabular}{ccc}
\hline Knowledge & Frequency & $\begin{array}{c}\text { Percent } \\
(\mathbf{\%})\end{array}$ \\
\hline Good & 8 & 26.7 \\
Border & 18 & 60.0 \\
Less & 4 & 13.3 \\
\hline Summary & $\mathbf{3 0}$ & $\mathbf{1 0 0}$ \\
\hline
\end{tabular}

From the research results it can be seen that as many as 8 respondents $(26.7 \%)$ have good knowledge, it is known from the questionnaire 18 respondents (60\%) have sufficient knowledge, 4 respondents (13.3\%) have less knowledge 


\section{DISCUSSION}

Based on the results of research conducted on 30 respondents, it can be seen that as many as 8 respondents (26.7\%) had good knowledge, 18 respondents $(60 \%)$ had sufficient knowledge, and 4 respondents (13.3\%) had less knowledge about diet.

Nutritional status during pregnancy is one of the important factors in determining fetal growth. The nutritional status of pregnant women will have an impact on birth weight, perinatal mortality, perinatal health, and growth of the baby after birth. One of the factors that influence the nutrition of pregnant women is the knowledge of pregnant women and their families about nutrients in food. The preparation of a pregnant woman's diet is influenced by the ability of the family to buy food and knowledge of nutrition.

The mother's ignorance about a good diet during pregnancy, eating will affect her daily eating habits, which certainly holds the important principle of being full regardless of nutritional content. Food intake that is in accordance with the needs during pregnancy is important to achieve good nutrition for the mother and the baby she is carrying. sufficient nutrition to provide the necessary nutrition for a healthy pregnancy, and reduce the risk of developing a baby with disabilities. The wrong diet in pregnant women has an impact on the occurrence of nutritional disorders, including anemia, low weight gain in pregnant women and fetal growth disorders (Samhadi, 2017).

Based on the results of the study, it was found that most of the pregnant women with high school / vocational education were 23 people $(76.7 \%)$. Education is a learning process which means that in education there is a process of growth, development or change towards a more mature, better and more mature individual, group or society.

Someone's education affects one's knowledge. In general, the higher a person's education level, the better his / her knowledge to receive and digest information, as well as low education contributes to how much someone's knowledge is. However, it should be emphasized that someone with low education is not always absolutely low-knowledge either

This is in line with the research conducted by Daba, namely that there are several factors that affect the knowledge of pregnant women about pregnant women nutrition, namely age, mother's educational status, family income, information about nutrition during pregnancy, the number of pregnancies before the current pregnancy and the gap between pregnancies. strong statistical relationship with maternal knowledge of nutrition during pregnancy.

One of the factors that influence the nutrition of pregnant women is the knowledge of pregnant women and their families about nutrients in food. The preparation of a pregnant woman's diet is influenced by the ability of the family to buy food and knowledge of nutrition. Based on research conducted by Surasih, the lack of knowledge of pregnant women about nutrition during pregnancy can lead to a lack of nutritious food during pregnancy because basically knowledge of pregnant women nutrition is very useful for the mother herself, therefore the need for energy and other nutrients is greatly increased during pregnancy. Mothers with good knowledge understand correctly how much it is necessary to increase energy and sufficient nutrients to make the fetus grow perfectly

From the results of interviews, pregnant women consume rice at least three times a day. The results of this study are in line with the research of Narasiang, et al. (2016) who found that the most carbohydrate source food consumed by pregnant women in Manado City is rice. Pregnant women need more food intake than before pregnancy. The fulfillment of increased food intake plays an important role in the health of the mother and the fetus (Pritasari, 2017; Ramussen, 2009). The results showed that the most frequently consumed protein sources were fresh chicken and fish.

Based on the work of mothers, most $(27.3 \%)$ housewives have sufficient knowledge, this is possible that housewives have plenty of time to access information via electronic media and participate in community activities.

\section{CONCLUSION}

More than half $(60 \%)$ of respondents have sufficient knowledge about diet

\section{SUGGESTION}

1. For Respondents

Can increase respondents' knowledge and increase motivation or guidelines for mothers about choosing a diet for pregnant women with weight gain in the third trimester. 
2. For Research Sites

Can be used as information for further research. The relationship between maternal knowledge about the diet of pregnant women and weight gain in the third trimester.

3. For the Institute of Education

The results of this study can be used as an addition to the UniversitasBatam Midwifery academic library and as a reference for researchers, especially those related to the knowledge of pregnant women about diet with weight gain in the third trimester.

4. For Further Researchers

The results of this study can be used as an addition to the UniversitasBatam Midwifery academic library and as a reference for researchers, especially those related to the knowledge of mothers about diet with weight gain in the third trimester.

5. For Researchers

Can add insight, even input, and knowledge for researchers. It can even add to the experience of researchers in conducting health research by developing the knowledge gained in lectures in real situations.

\section{DAFTAR PUSTAKA}

Anjani, A. D., \& NurulAulia, D. L. (2017). HUBUNGAN PENGETAHUAN KEPALA KELUARGA TENTANGBADAN PENYELENGGARA JAMINAN SOSIAL (BPJS) DENGAN KEIKUTSERTAAN DALAM PENGGUNAANBADAN PENYELENGGARA JAMINAN SOSIAL DI KELURAHAN BELIAN KOTA BATAM. Jurnal Kebidanan Malahayati, 3(2)

Alfitra. 2013. Gizi Kehamilan, http//blogspot.com

Aulia, Devy Lestari Nurul; Anjani, Arum Dwi. (2017). Hubungan Keikutsertaan Badan Penyelenggaraan Jaminan Kesehatan (BPJS) terhadap kepatuhan Kunjungan Antenatal Care (ANC). Zona Keperawatan $8(1), 75-80$

Depkes RI,2015 Profil kes Indonesia.Jakarta: Kementerian Kesehatan RI

Dainty Maternity, S. S. T., Keb, M., \& Anjani, A. D. (2018). ASUHAN KEBIDANAN NEONATUS, BAYI,
BALITA, DAN ANAK PRASEKOLAH. Penerbit Andi

Harefa, (2016)Hubungan pengetahuan ibu hamil tentang pola makan dengan kenaikan berat badan trimester III di Klinik Madina Medan, kebidanan Helvetia Medan.

Lumbantoruan SL. Hubungan Pengetahuan Ibu Hamil Tentang Pola Makan Dengan Kenaikan Berat Badan Pada Trimester III. Medan: Akademi Kebidanan Helvetia;2015

Maternity, Dainty; Ratna, DP; Devy, LNA. (2017). Asuhan Kebidanan KomunitasDisesuaikan dengan Rencana Pembelajaran Kebidanan. Penerbit Andi, Yogyakarta

Muhammad. Panduan penyusunan Karya Tulis Ilmiah Bidang Kesehatan Menggunakan Metode Ilmiah Bandung: Cita pustaka media perintis; 2015.

Mochtar, 2014. Sinopsis Obstetri, Jakarta :EGC

Nursalam dan Pariani, 2013 Konsep dan Penerapan Metodologi Penelitian Ilmu Keperawatan, PT Salemba Medika.

Nurhalimar Tanjung. Hubungan tingkat ibu hamil tentang pola makan dengan kejadian anemia di rumah bersalin Hanum Tanjung Mulia Medan 2013

Pudjiadi , 2013, Ilmu Gizi klinis pada Anak, Jakarta, Balai Penerbit FKUI.

Prawiroharjo, $\quad$ Sarwono. 2008. PelayananKesehatan Maternal dan Neonatal. Jakarta: Yayasan Bina Pustaka Sarwono Prawirohardjo

Prita SO. Pola Makan dan Gaya Hidup Sehat Selama Kehamilan Yogyakarta:Nuha Medika;2015

Sarwono, 2015, Buku Acuan Nasional Kesehatan Maternal dan Neonatal Kesehatan Maternal dan Neonatal, Jakarta, YBP-SP. 
Sayogo, 2013. Gizi ibu Hamil. Jakarta : Balai Penerbit Fakultas Kedokteran Universitas Indonesia

Syarifah Umniati. Hubungan Tingkat Pengetahuan Gizi, Sikap, Pola Makan, dan Tingkat Stress Ibu Hamil Terhadap Kenaikan Berat Badan Ibu di Poli Kebidanan Rumah Sakit Mitra Keluarga Bekasi. 2013 Apri;p.1

Sri Wahyuni, I, 2008, Hubungan Antara Pengetahuan Ibu Hamil Tentang Gizi dengan Status Gizi Ibu Hamil di Puskesmas Nusukan Surakarta,Universitas Sebelas Maret Surakarta.

Sugiyono, 2003. Statistik Untuk Penelitian.Alfabeta, Bandung.

Suharsini, A, Dr, 2000. Prosedur Penelitian Suatu Pendekatan Praktek,Yogyakarta : Rineka Cipta.

Sunandar, 2004. Hubungan Status Lila Dan Kadar HBTrimester III Dengan Berat Bayi Lahir di Puskesmas Mojosongo Kabupaten Boyolali. Jawa Tengah.

Supariasa, I., Bakrie, B., Fajar, L, 2002. Penilaian Status Gizi, Jakarta : EGC.Saryono, 2009. Metodologi Penelitian Kesehatan, Yogyakarta : Mitra Cendikia.

Tanjung N. Hubungan Pengetahuan Ib Hamil Tentang Pola Makan Dengan Kejadian Anemia. Medan: Akademi Kebidanan Helvetia;2015

Verney, 2013, Buku Ajar Asuhan Keperawatan. Jakarta: EGC

winkjosastro, Hanifa, 1999. Ilmu Kebidanan. Jakarta: YBP-SP.Zulhaida, 2003, Status Gizi Ibu Hamil Serta Pengaruhnya Terhadap Bayi yang Dilahirkan.GMK. 